\title{
ANALYSIS OF WIGNER ENERGY IN BGRR GRAPHITE
}

\author{
(FINAL ANALYSIS)
}

M. Fuhrmann

November 2006

\author{
Environmental Sciences Department \\ Environmental Research \& Technology Division \\ Brookhaven National Laboratory \\ P.O. Box 5000 \\ Upton, NY 11973-5000 \\ www.bnl.gov
}

Notice: This manuscript has been authored by employees of Brookhaven Science Associates, LLC under Contract No. DE-AC0298CH10886 with the U.S. Department of Energy. The publisher by accepting the manuscript for publication acknowledges that the United States Government retains a non-exclusive, paid-up, irrevocable, world-wide license to publish or reproduce the published form of this manuscript, or allow others to do so, for United States Government purposes. 


\section{DISCLAIMER}

This report was prepared as an account of work sponsored by an agency of the United States Government. Neither the United States Government nor any agency thereof, nor any of their employees, nor any of their contractors, subcontractors, or their employees, makes any warranty, express or implied, or assumes any legal liability or responsibility for the accuracy, completeness, or any third party's use or the results of such use of any information, apparatus, product, or process disclosed, or represents that its use would not infringe privately owned rights. Reference herein to any specific commercial product, process, or service by trade name, trademark, manufacturer, or otherwise, does not necessarily constitute or imply its endorsement, recommendation, or favoring by the United States Government or any agency thereof or its contractors or subcontractors. The views and opinions of authors expressed herein do not necessarily state or reflect those of the United States Government or any agency thereof. 


\title{
Analysis of Wigner Energy in BGRR Graphite
}

\author{
Mark Fuhrmann \\ Environmental Sciences Dept. \\ Brookhaven National Laboratory
}

Eight segments (4" long slugs) of cores were obtained from BGRR for analysis of Wigner Energy retained in the graphite. Graphite was scraped from each end of each slug giving two samples from each specimen. Between 10 and $20 \mathrm{mg}$ of this graphite powder were weighed into platinum analysis cells and subjected to thermal analysis on a Shimadzu Differential Scanning Calorimeter (DSC-50). The samples were annealed in nitrogen up to $700^{\circ} \mathrm{C}$ at a scan rate of $20^{\circ} \mathrm{C} /$ minute with data recorded at one second intervals. Each sample was run twice; the first scan provided the energy profile of the "as received" material and the second scan provided the background energy profile of the specimen, as the Wigner Energy had been removed during the first annealing. An example is shown in Figure 1. The blank was subtracted from the initial scan to give the Wigner energy profile. The appendix contains two graphs for each sample. One graph presents the data in $\mathrm{J} / \mathrm{s} / \mathrm{g}$ and shows the results of the two scans described above; the energy measurement of the 'as received' and the same sample after annealing. The other graph presents the data in $\mathrm{J} / \mathrm{g} / \mathrm{K}$, which was calculated by subtracting the background scan data from the first scan and dividing by the heating rate. The heating rate was nominally $20 \mathrm{~K} / \mathrm{minute}$ $(0.333 \mathrm{~K} / \mathrm{s})$, however regression analysis provided a more accurate heating rate of $0.3506 \mathrm{~K} / \mathrm{s}$ and this was used to determine $\mathrm{J} / \mathrm{g} / \mathrm{K}$. These values were plotted against temperature in $\mathrm{C}$. From these plots the temperature at which energy release increases can be determined. The data $(\mathrm{J} / \mathrm{s} / \mathrm{g})$ were summed providing a measure of total Wigner energy in the sample in Joules per gram.

The DSC analysis gives energy content of the graphite that ranges from around 0 (actual measurements of samples from Loc 4 slug 3 were -2.9 and $-21.2 \mathrm{~J} / \mathrm{g}$ ) to $212 \mathrm{~J} / \mathrm{g}$. Table 1 gives the location and the total energy content of each sample. Figure 2 contains background subtracted scans showing two groups of peak energy release rates. The group with the greatest release rates peaks between 250 and $260^{\circ} \mathrm{C}$. These samples, with the greatest amount of stored energy, reached their maximum release rate within about $100^{\circ} \mathrm{C}$ of the start of release; peaking at about $1 \mathrm{~J} / \mathrm{g} / \mathrm{K}$ at analysis temperatures of $255^{\circ} \mathrm{C}$. The other group had much slower approaches to their maximum release rates and only reached it between 300 and $350^{\circ} \mathrm{C}$. Almost 
all samples began to show energy release at about $150^{\circ} \mathrm{C}$. Below this temperature very little if any energy was released. A sample of reactor graphite that had not been irradiated had a similar temperature profile to the background (annealed) samples (not shown).

Comparing four samples that show high energy deposition in Figure 3, the temperature at the initial release of energy is similar (about $150^{\circ} \mathrm{C}$ ) and the peak heights for maximum energy release are also similar. There are differences in total energy release (e.g. 13A slugs 9a and b are 211 and $123 \mathrm{~J} / \mathrm{g}$ respectively) which is the result of higher energy in the later portion of the scan; from about $300^{\circ} \mathrm{C}$ to $700^{\circ} \mathrm{C}$.

The samples taken from Location 4 slug number 3 show no Wigner energy. The initial scan and the subsequent blank scan are essentially identical, with energy deposition of -2.9 and $-21.2 \mathrm{~J} / \mathrm{g}$.

Table 2 shows the total energy measured in four background subtracted replicates of the sample from Location 13A slug 19a. The mean of the four replicates was $101 \mathrm{~J} / \mathrm{g}$ with a standard deviation of 30 . These scans are also shown in Figure 4 where they are compared to one of the high energy scans. 
Table 1. Stored Energy in BGRR Graphite Samples

\begin{tabular}{|c|c|c|c|c|c|c|}
\hline $\begin{array}{c}\text { Sample } \\
\text { Location }\end{array}$ & $\begin{array}{c}\text { Layer } \\
\text { Number }\end{array}$ & $\begin{array}{c}\text { Slug } \\
\text { Number }\end{array}$ & $\begin{array}{c}\text { Distance } \\
\text { from Pile } \\
\text { west side } \\
\text { (Inches) }\end{array}$ & $\begin{array}{c}\text { Distance } \\
\text { from Pile } \\
\text { center line } \\
(\mathbf{f t})\end{array}$ & $\begin{array}{c}\text { Graphite } \\
\text { Type }\end{array}$ & $\begin{array}{c}\text { Total } \\
\text { Energy } \\
(\mathbf{J} / \mathbf{g})\end{array}$ \\
\hline Loc 13A & 37 & 34 a and b & $132-136$ & (South)3.5 & $\mathrm{A}$ & $88.0,45.7$ \\
\hline Loc 13A & 37 & 11 a and b & $40-44$ & (South)3.5 & $\mathrm{D}$ & 204,209 \\
\hline Loc 13A & 37 & 49 a and b & $192-196$ & (South)3.5 & $\mathrm{A}$ & $65.0,145$ \\
\hline Loc 13 A & 37 & 19 a and b & $72-76$ & (South)3.5 & B & $147,70.7$ \\
\hline Loc 13 A & 37 & 16 a and b & $60-64$ & (South)3.5 & B & 177,113 \\
\hline Loc 13 A & 37 & 9 a and b & $32-36$ & (South)3.5 & D & 211,123 \\
\hline Loc 3 (I-5) & 65 & 33 a and b & $128-132$ & (South)6.0 & C & $105,49.0$ \\
\hline Loc 4 & 65 & 3 a and b & $8-12$ & (South)10.5 & D & $-21.2,-2.9$ \\
\hline
\end{tabular}

Table 2. Total Energy of 4 replicates

\begin{tabular}{|c|c|}
\hline Sample & Total energy J/g \\
\hline $13-19 \mathrm{a} \# 1$ & 145 \\
\hline $13-19 \mathrm{a} \# 2$ & 98.3 \\
\hline $13-19 \mathrm{a} \# 3$ & 78.4 \\
\hline $13-19 \mathrm{a} \# 4$ & 83.6 \\
\hline mean $($ std dev) & $101(30.3)$ \\
\hline
\end{tabular}




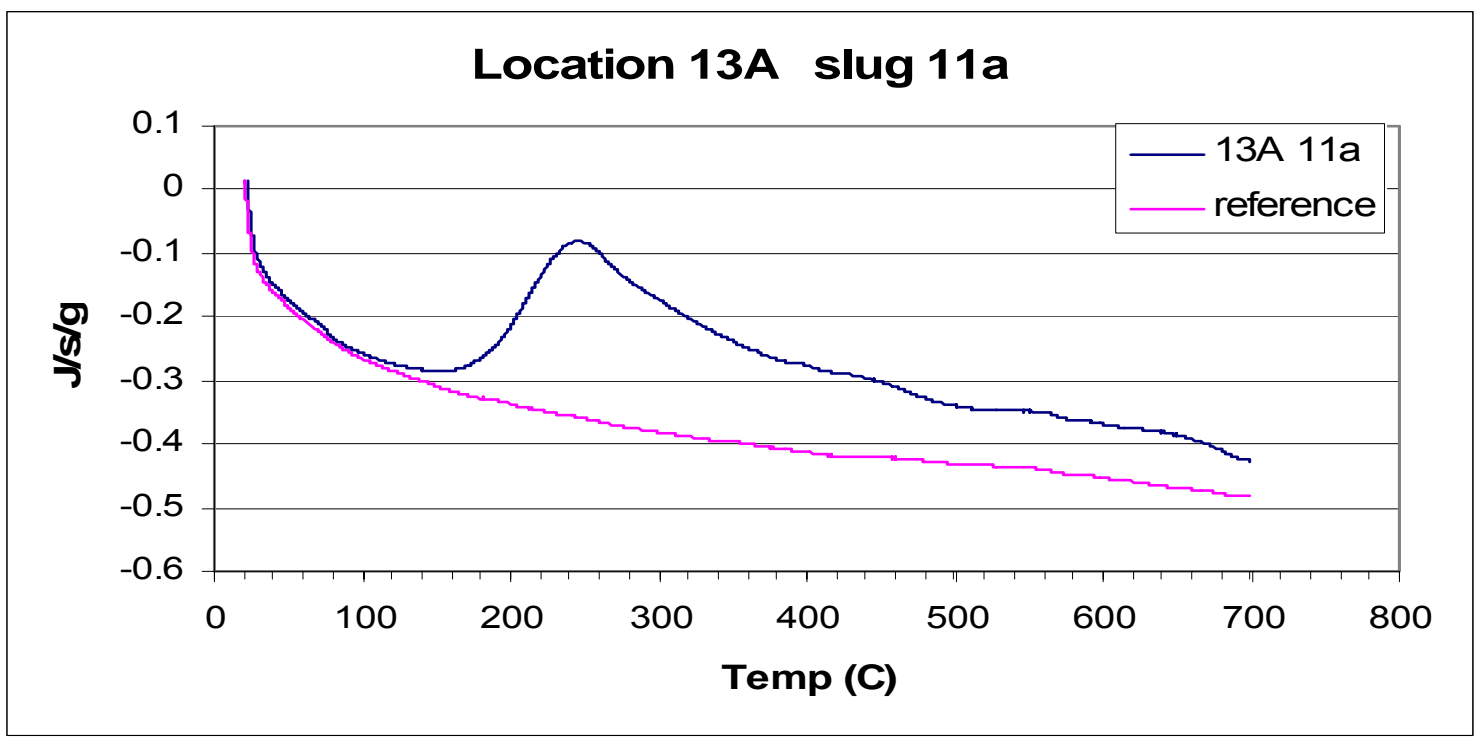

Figure 1. A pair of DSC scans showing the release of energy from the first scan and then the same sample rescanned after the energy had been released. Each sample was run twice to provide a blank which ascertained that the energy observed in the first scan was Wigner energy.

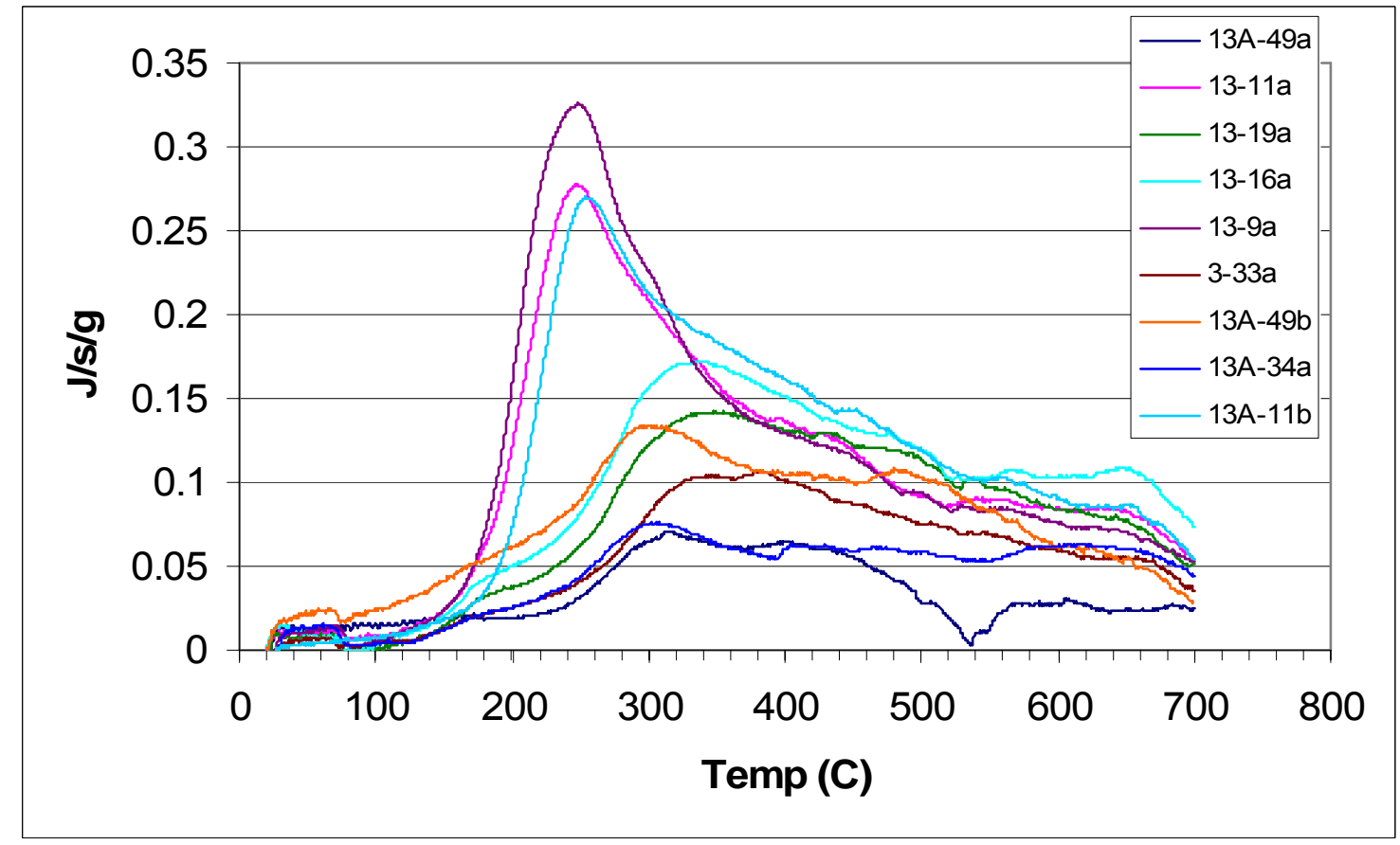

Figure 2. Background subtracted DSC scans of graphite samples from the BGRR interior. Summing the energy in each interval (1 second) gives area under the peak and a measure of total energy released. 


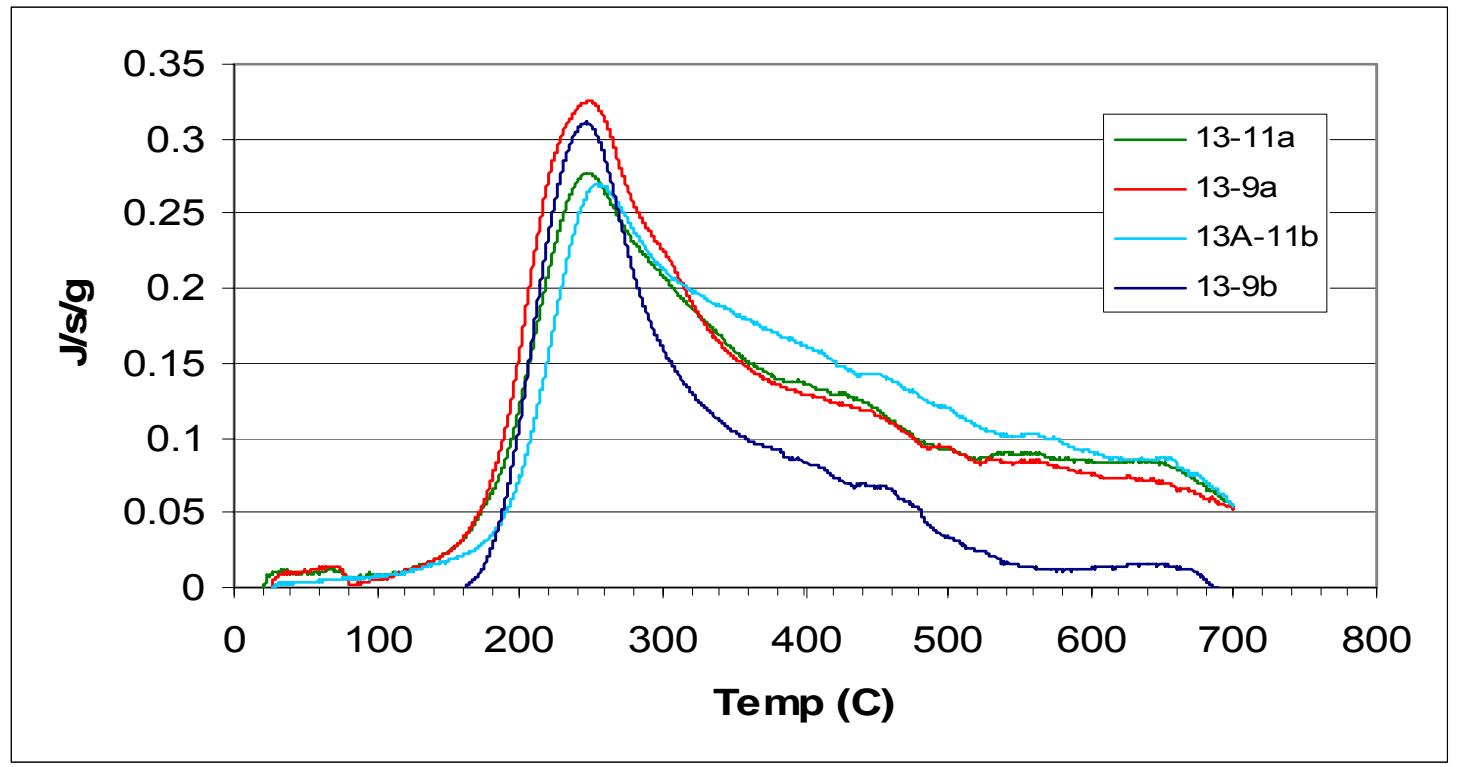

Figure 3. Background subtracted comparison of higher energy samples. Differences in total energy are primarily caused by different profiles in the latter portion of the scans.

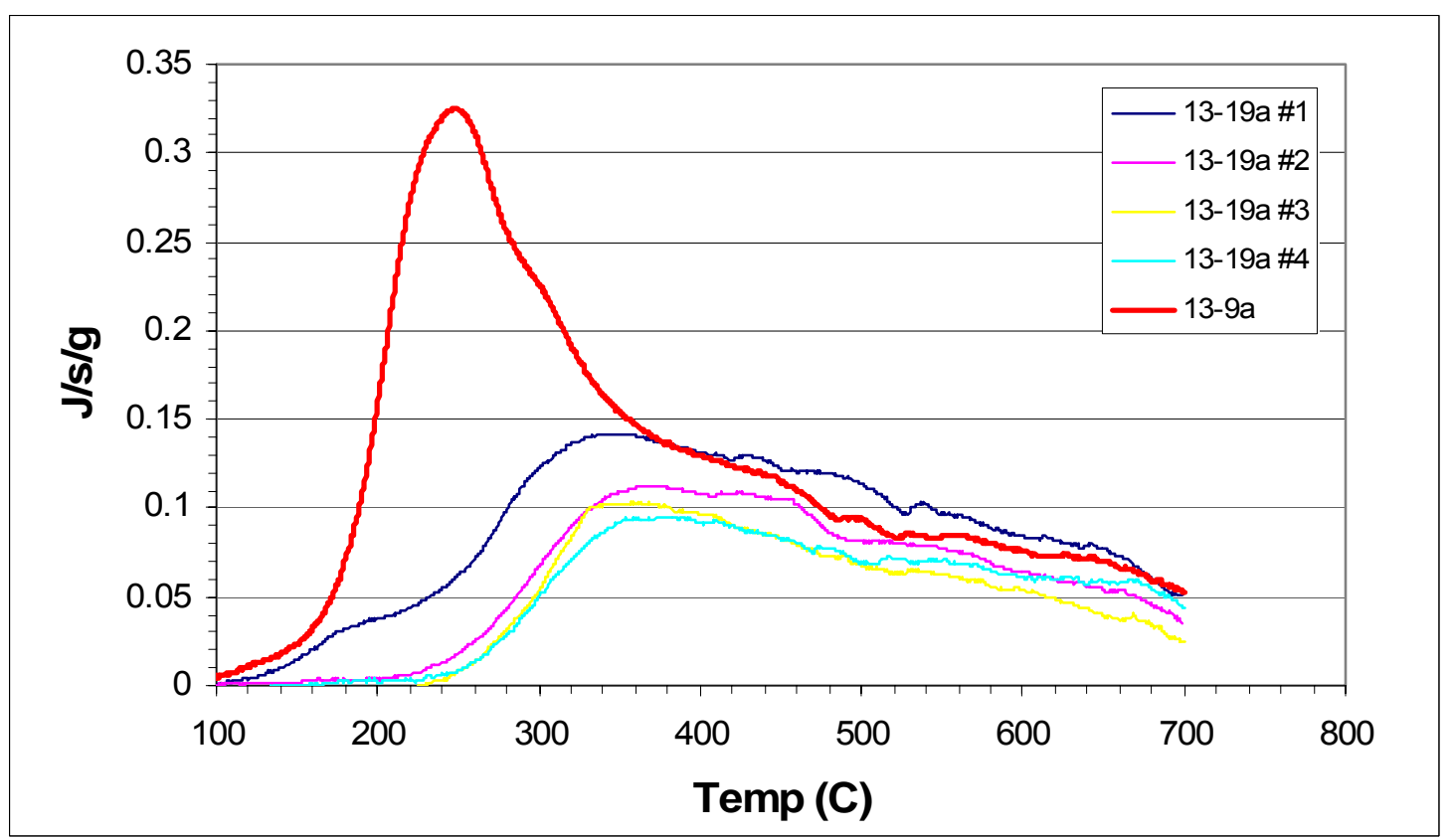

Figure 4. Four replicates of the sample from Location 13A slug 19a and a scan of a high energy sample for comparison. 


\section{APPENDIX 1}

\section{DSC Scans of BGRR Graphite}



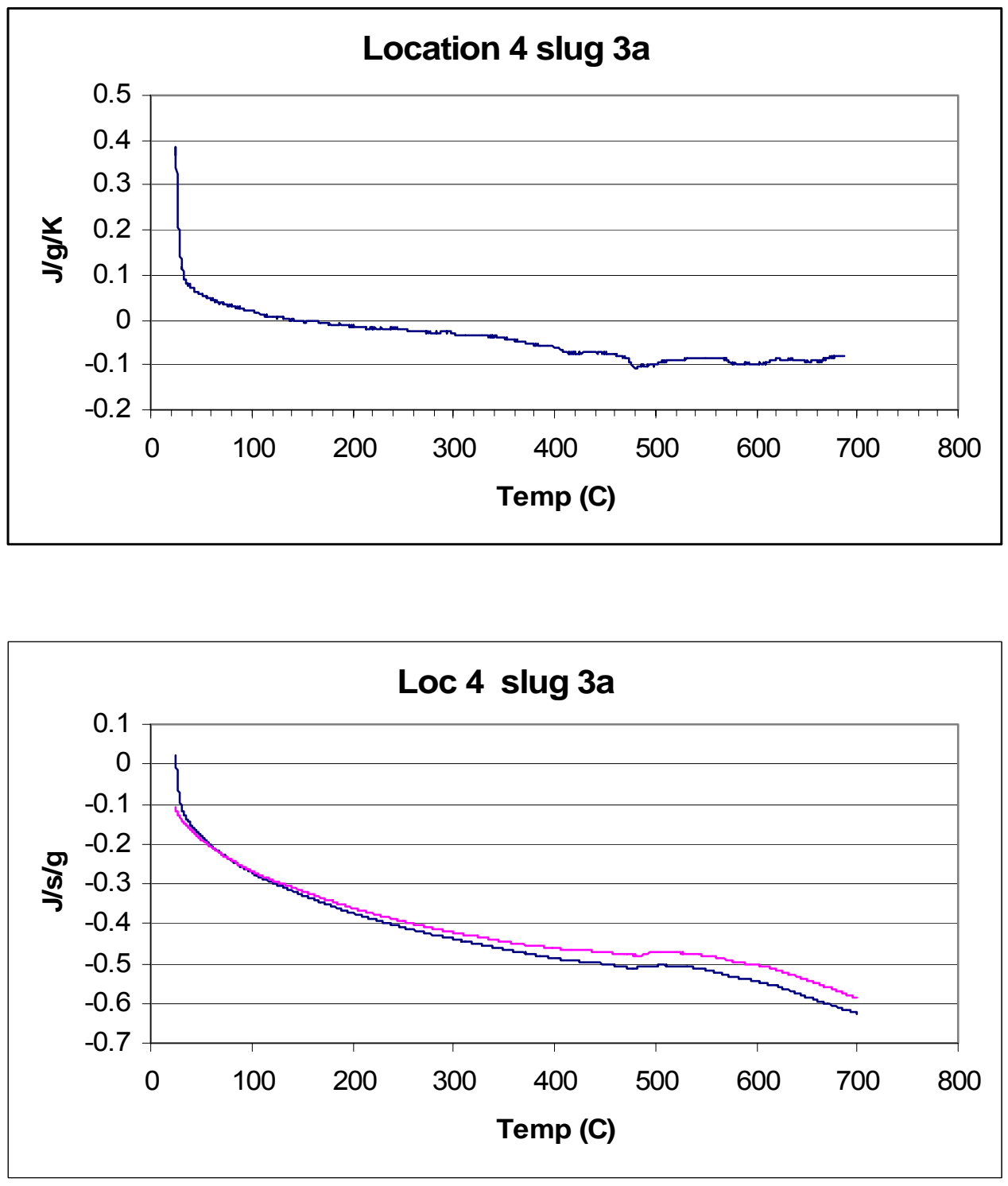

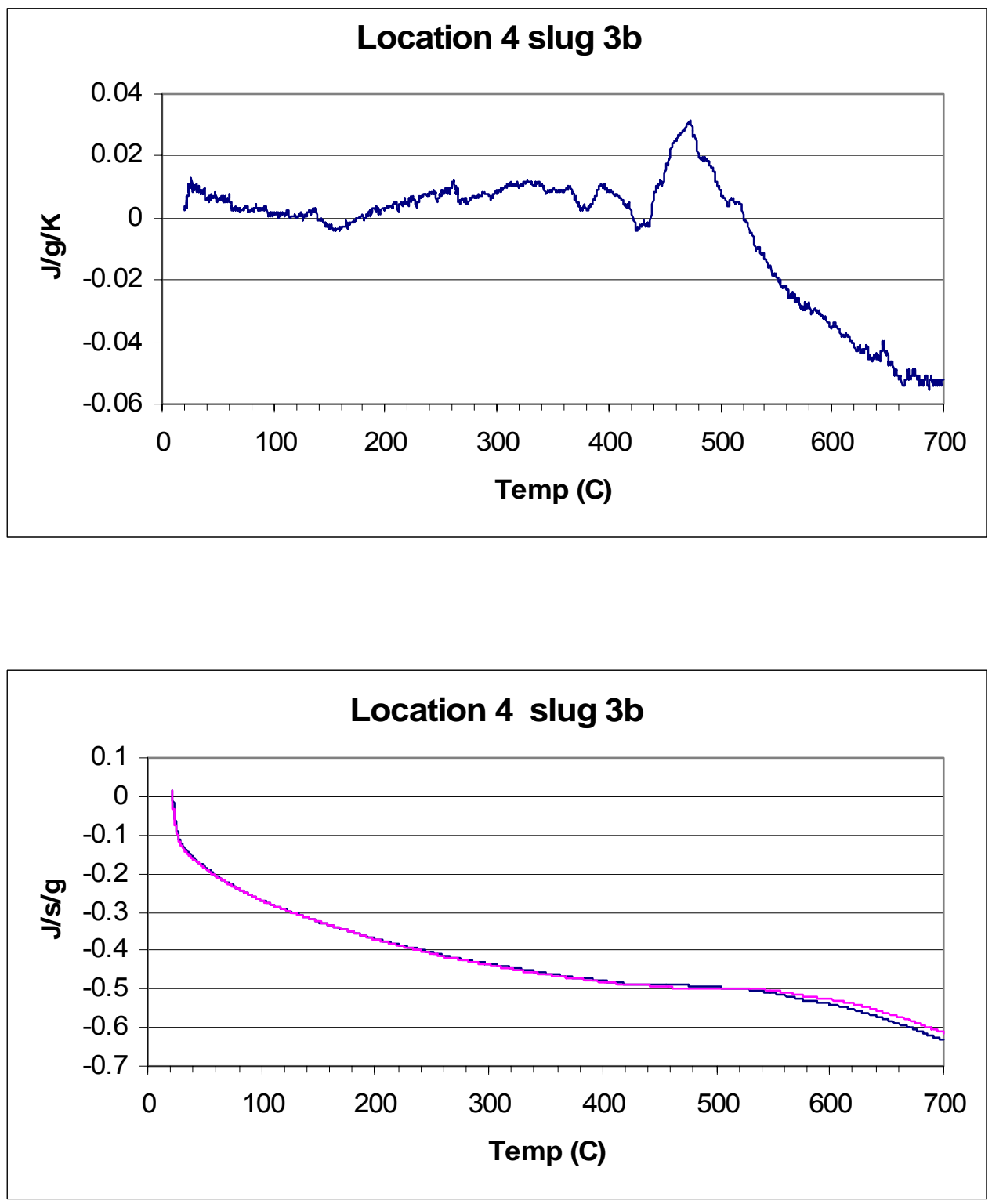

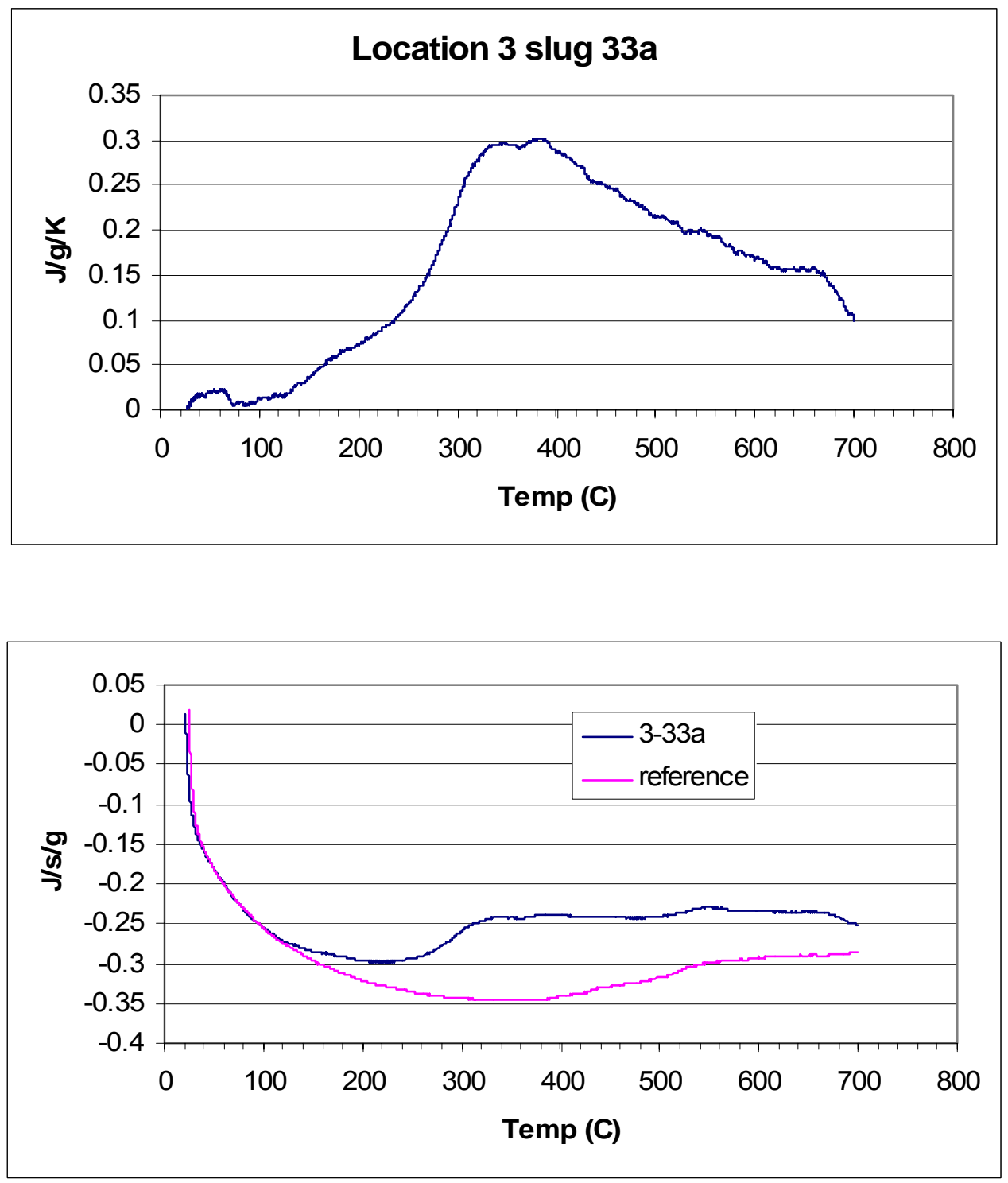

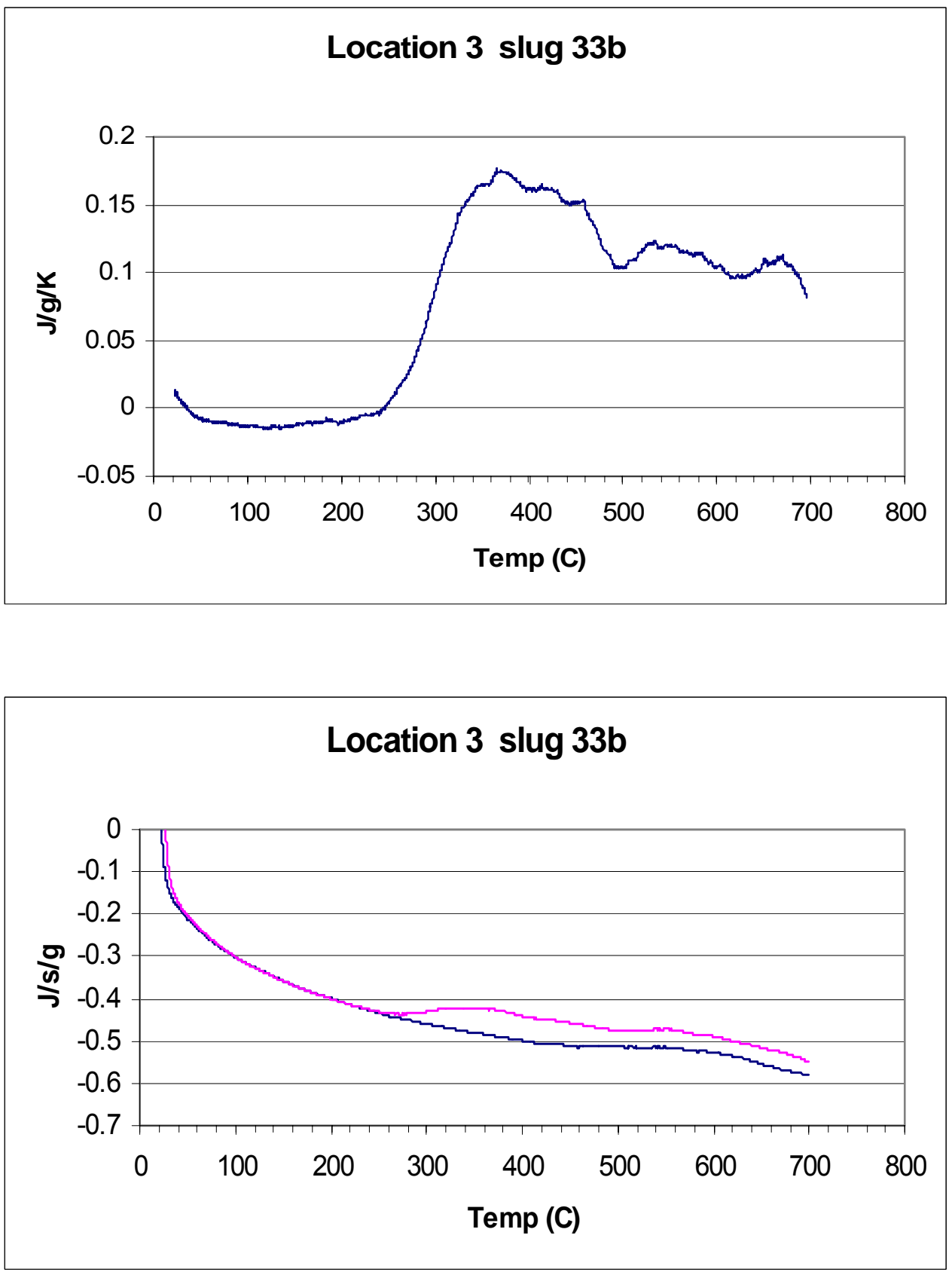

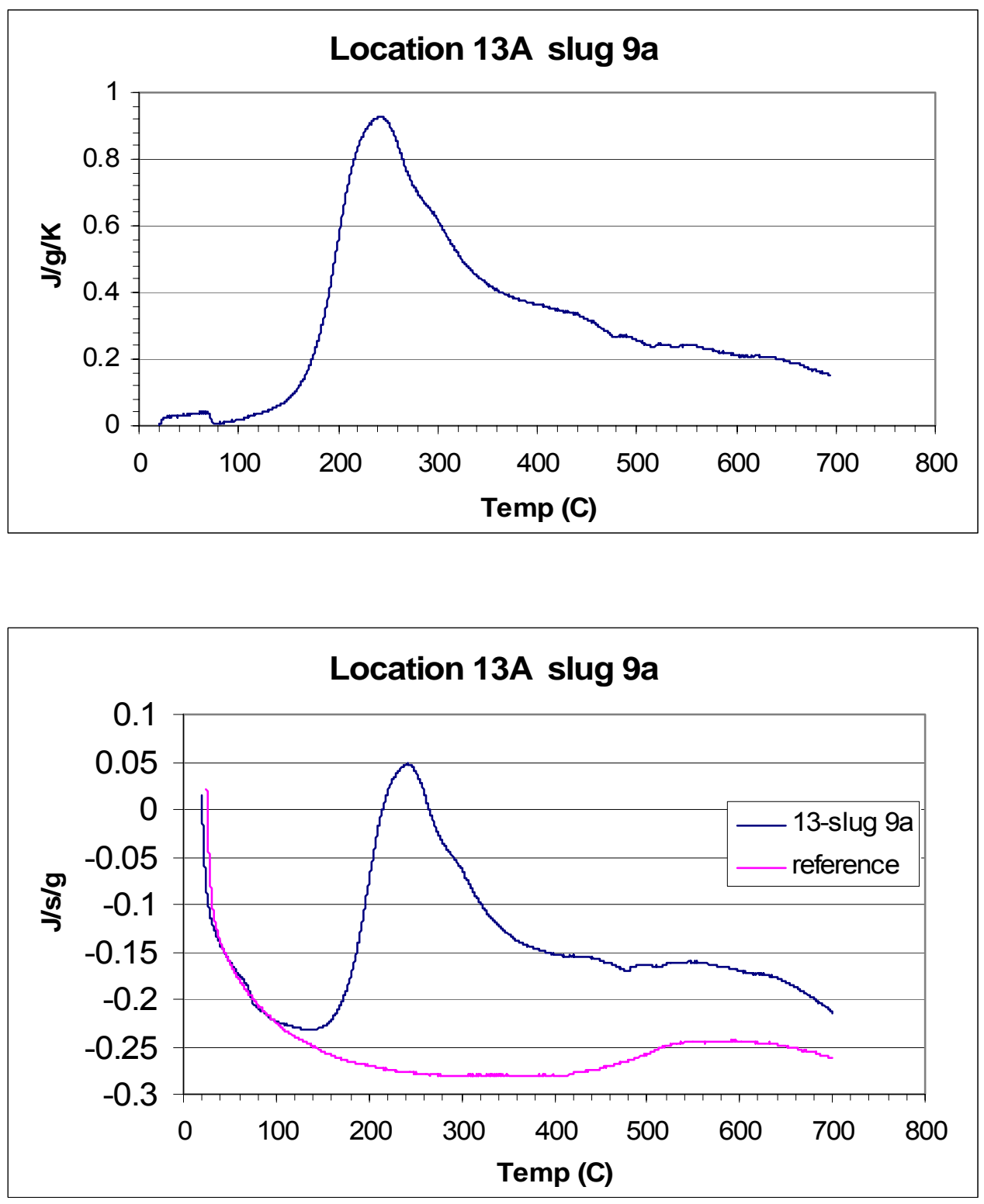

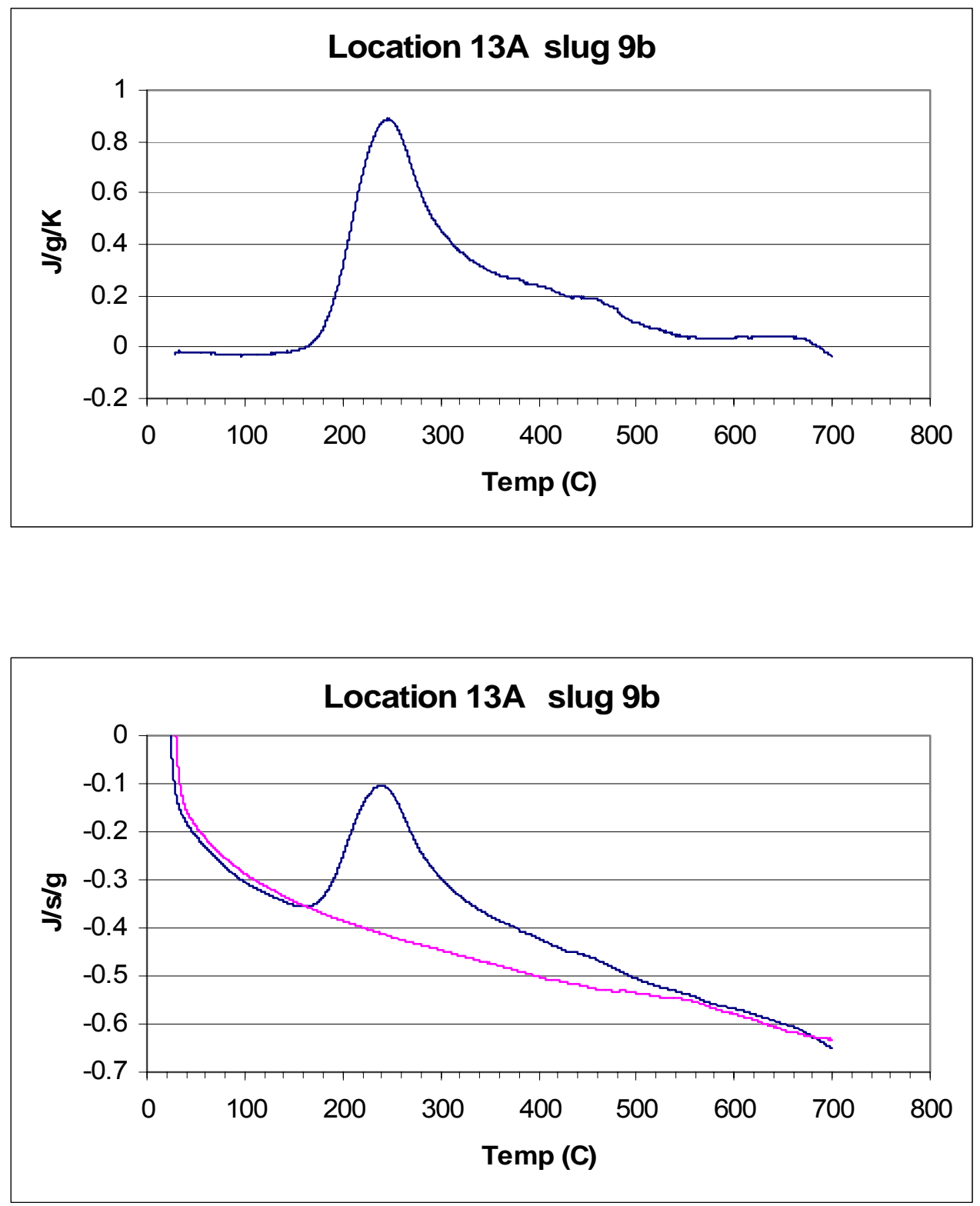

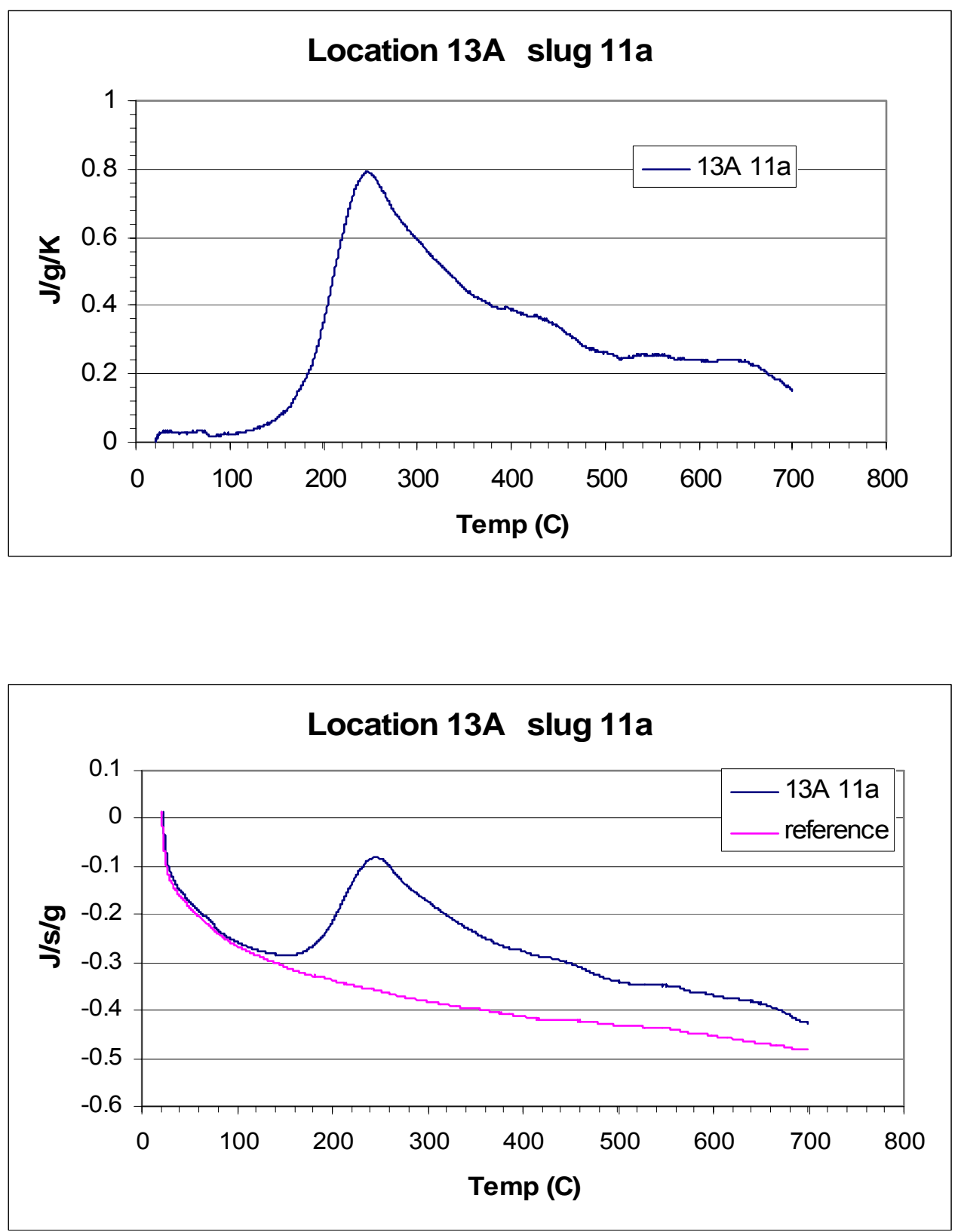

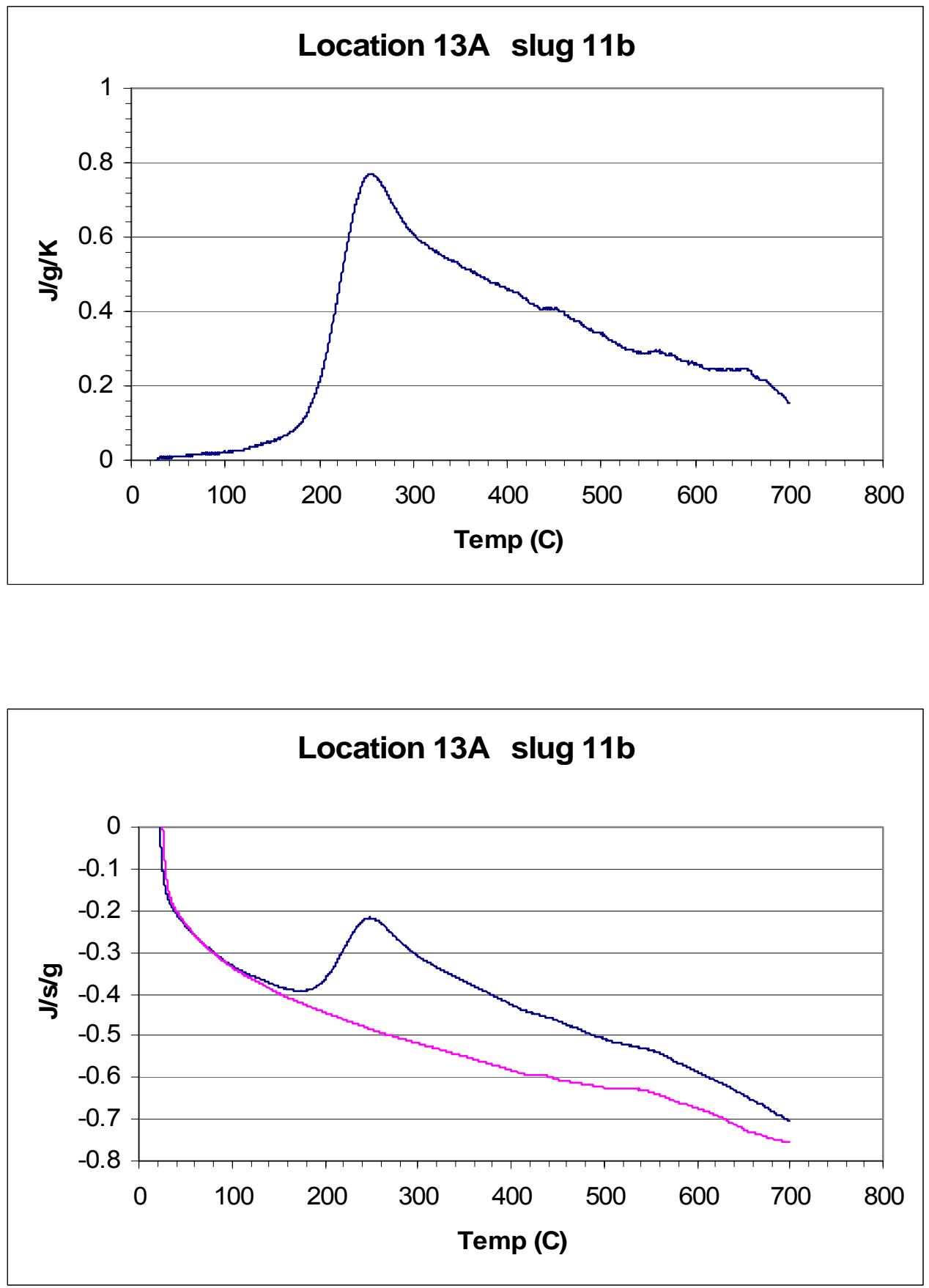

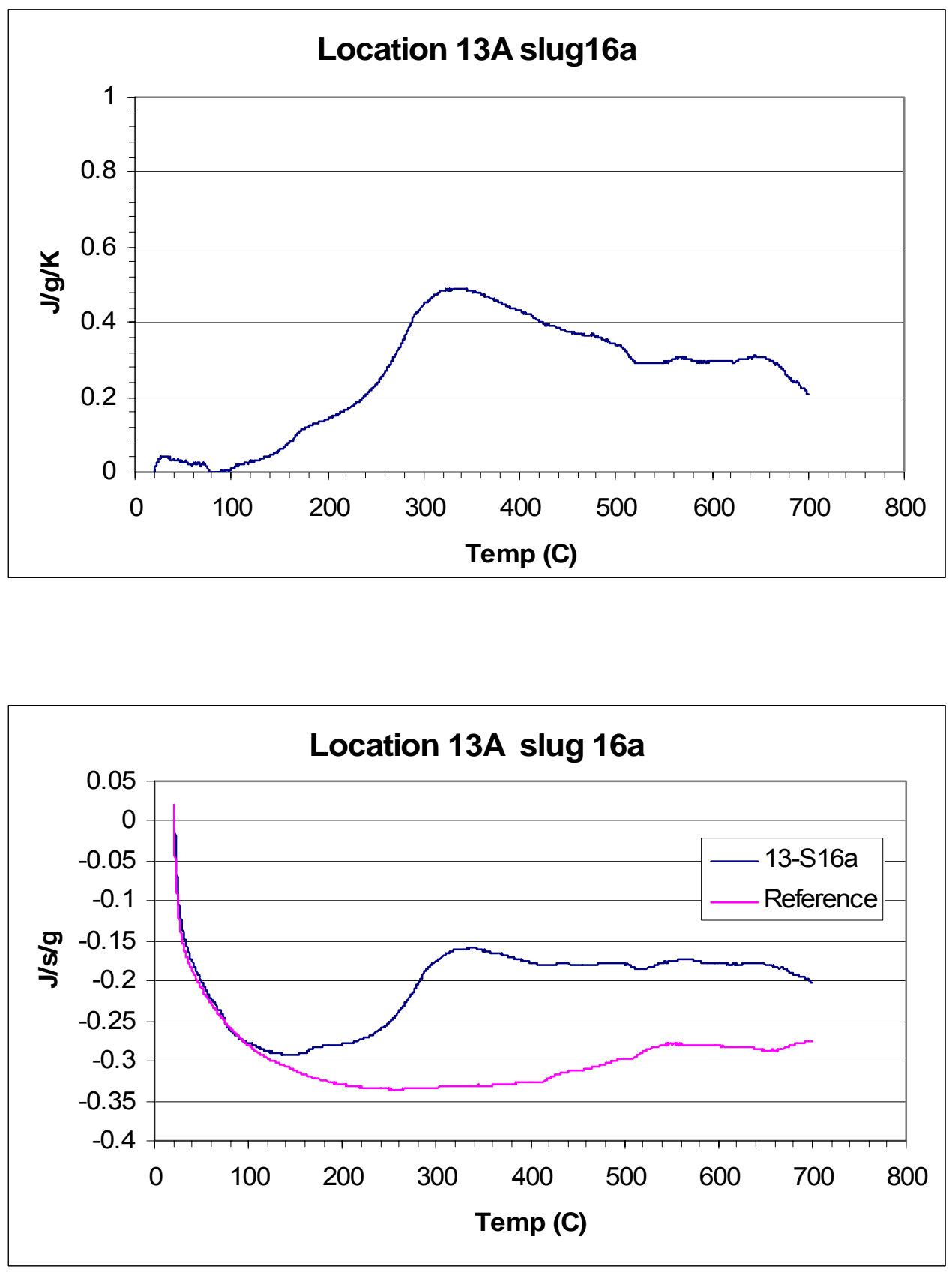

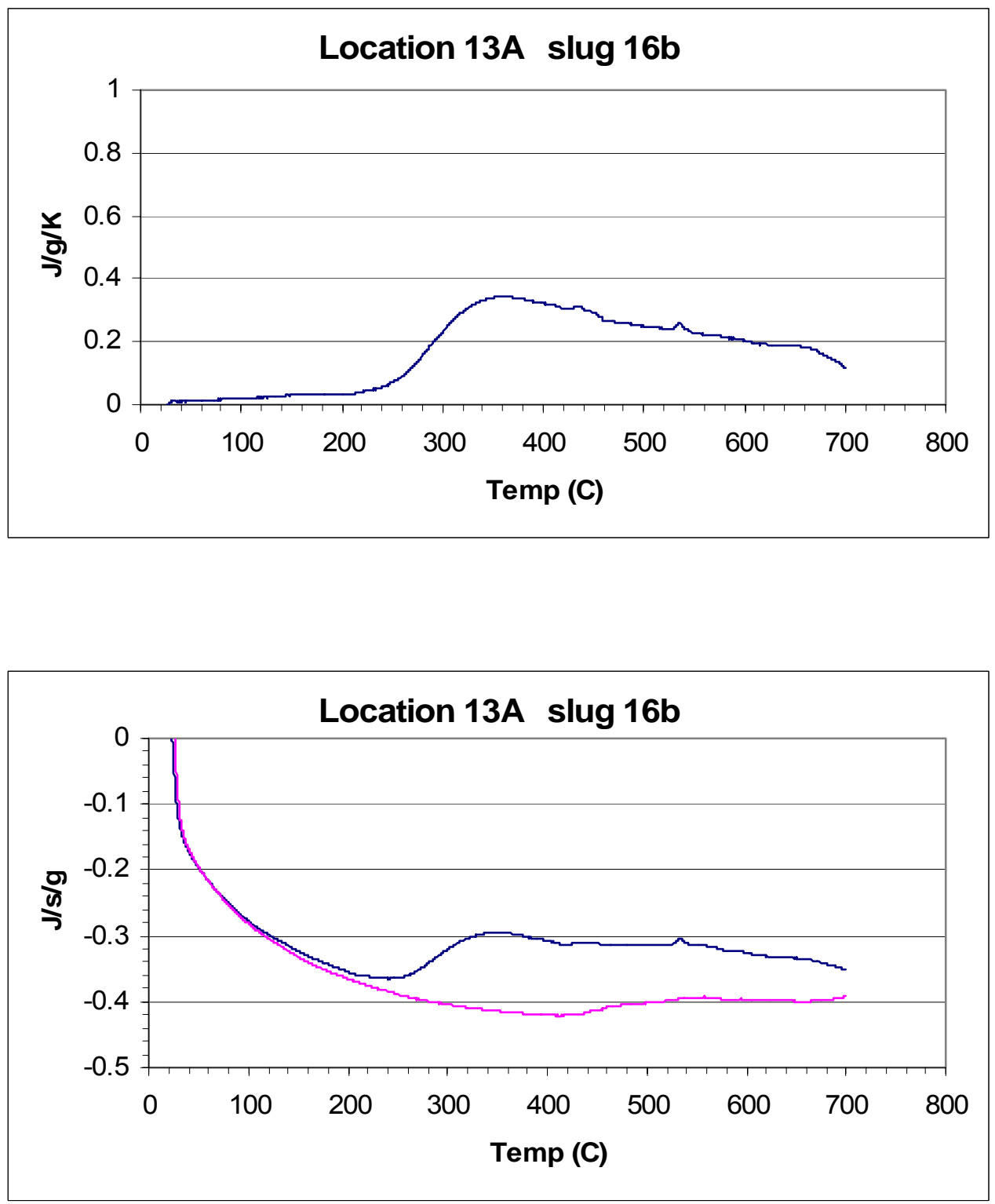

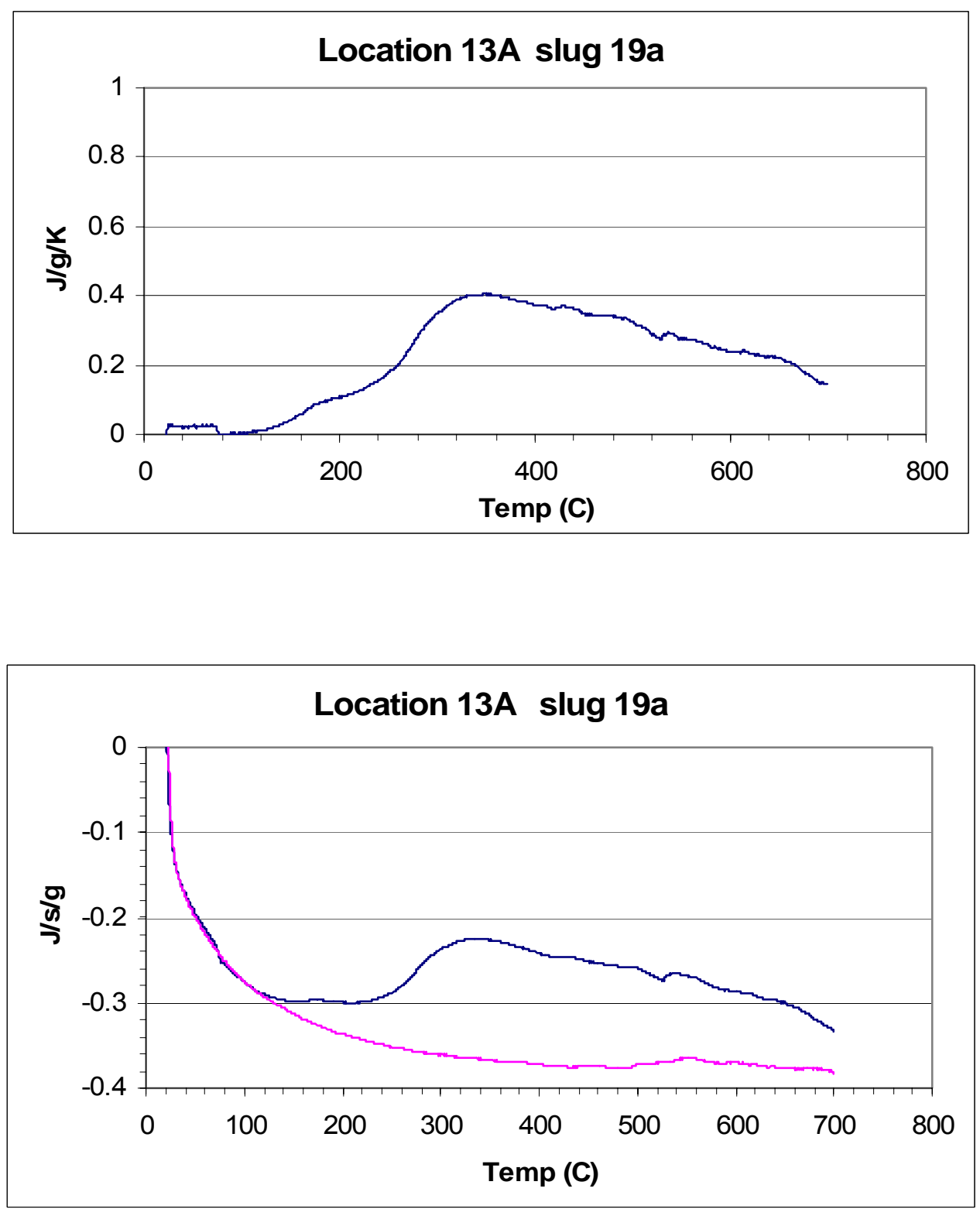

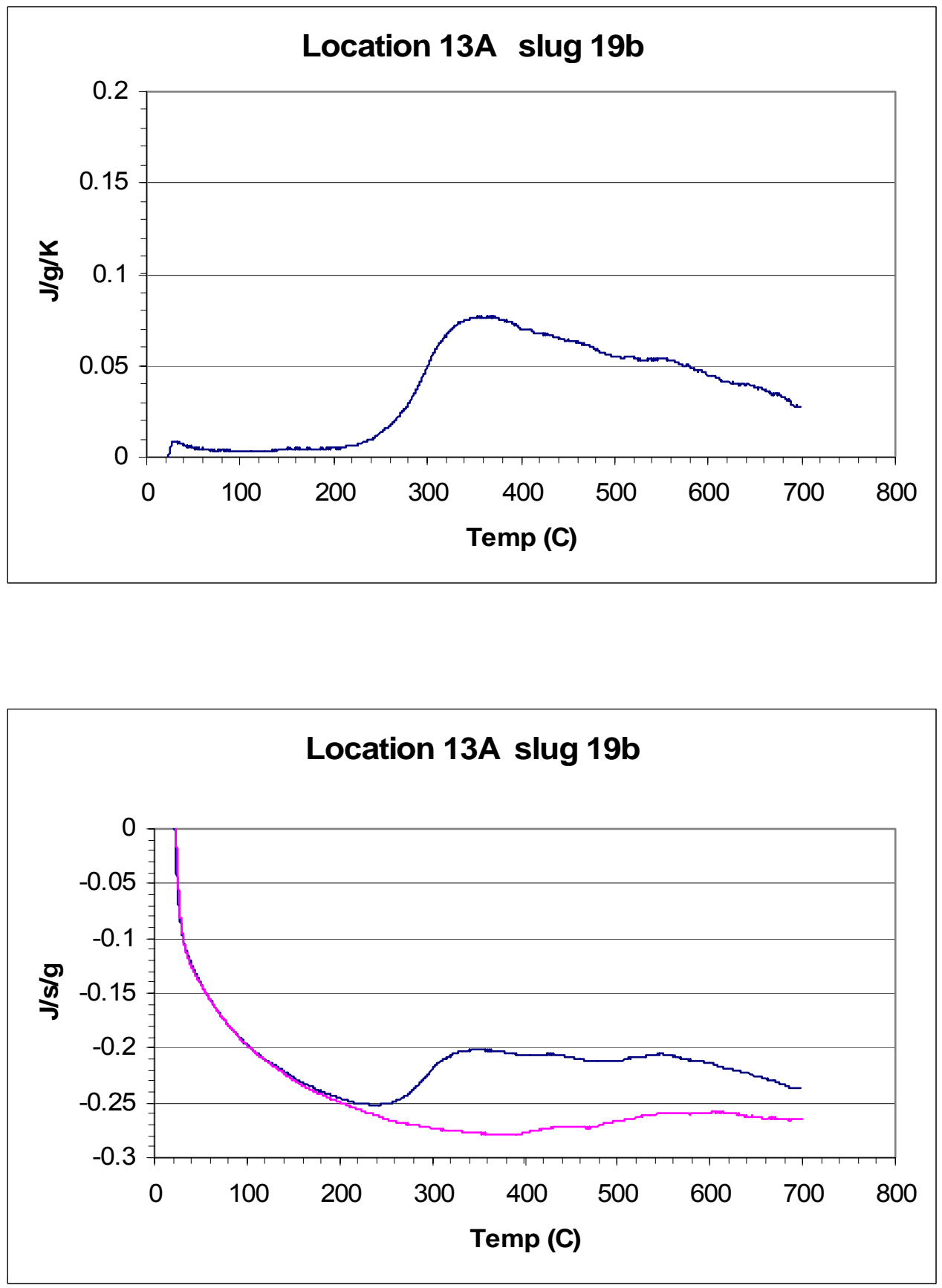

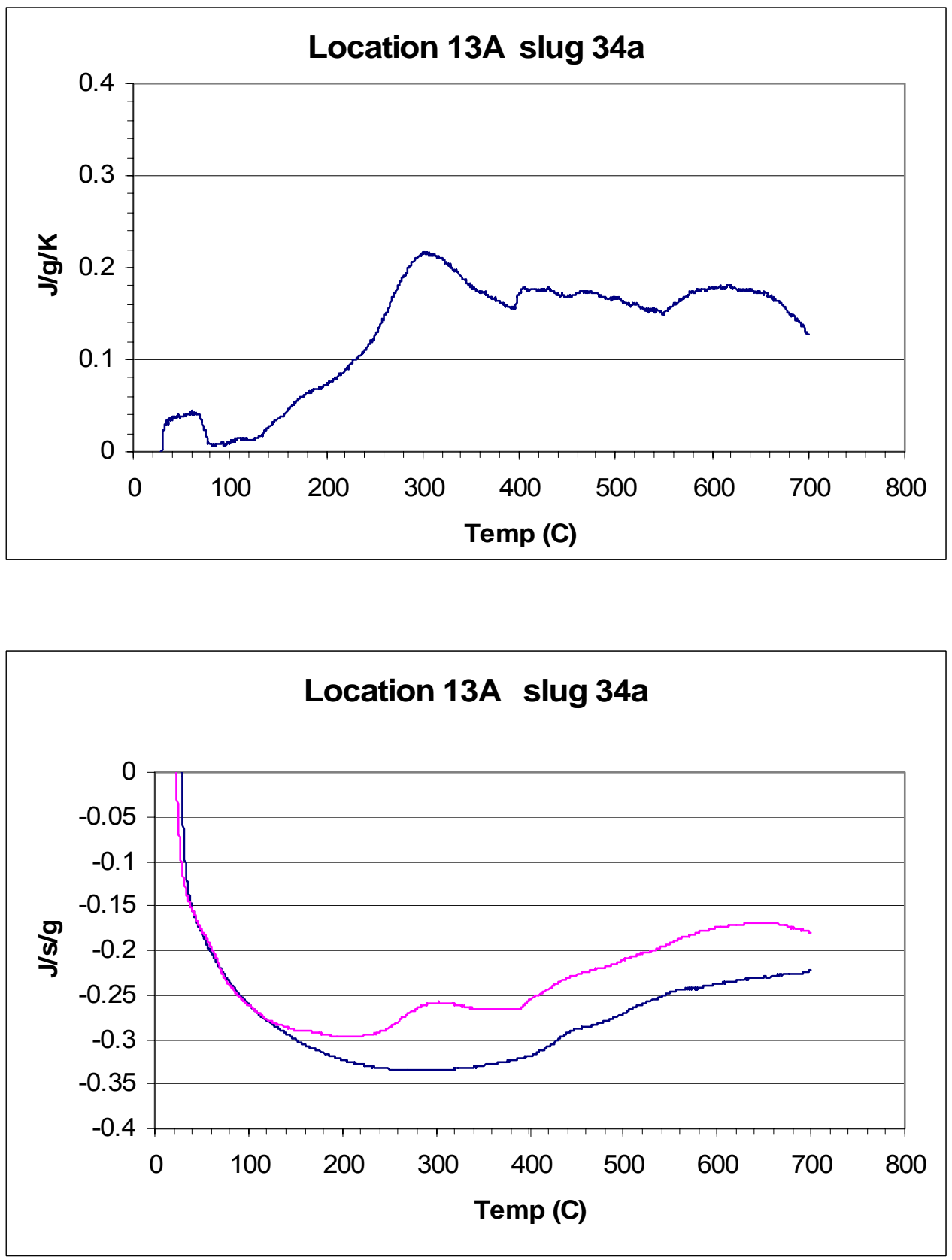

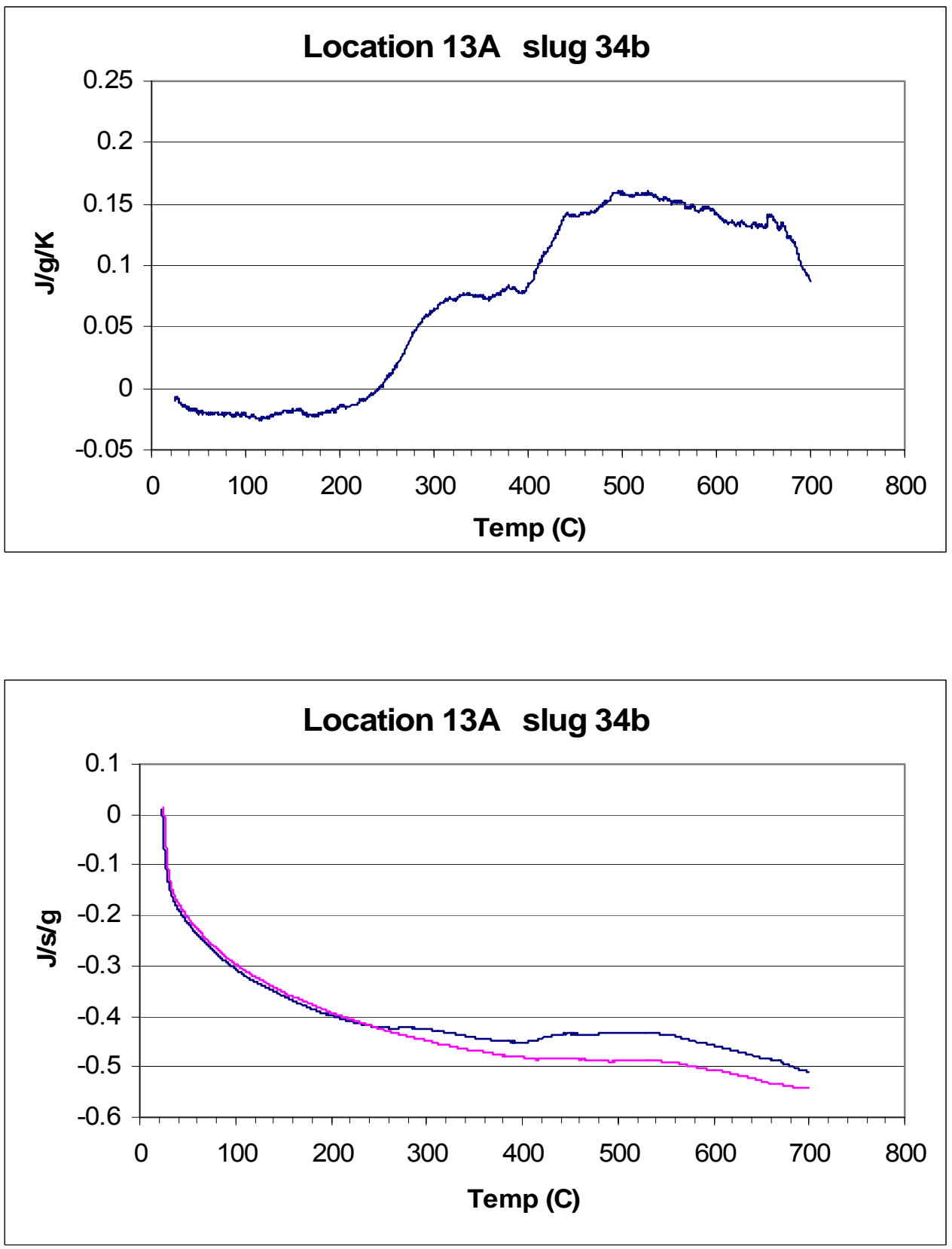

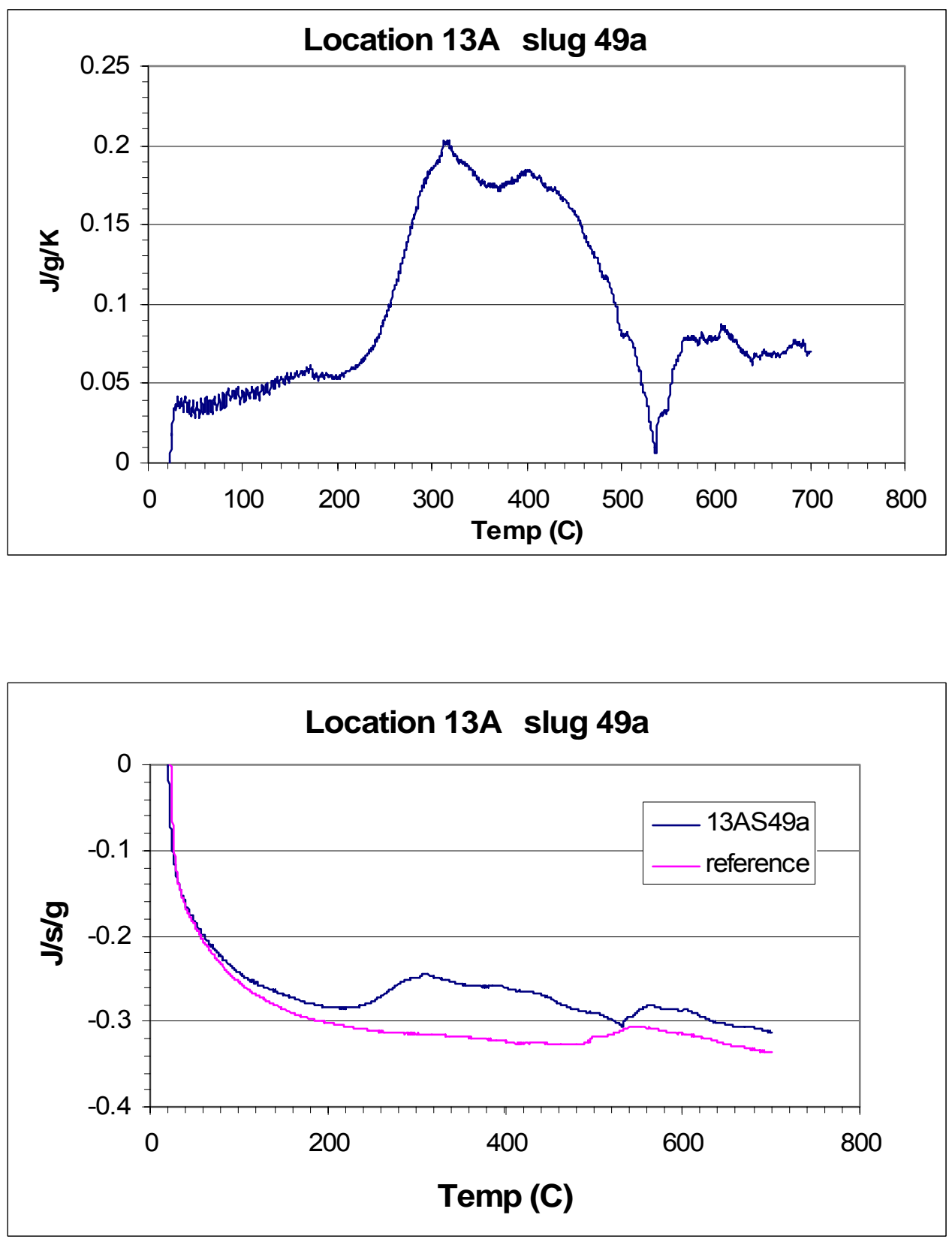

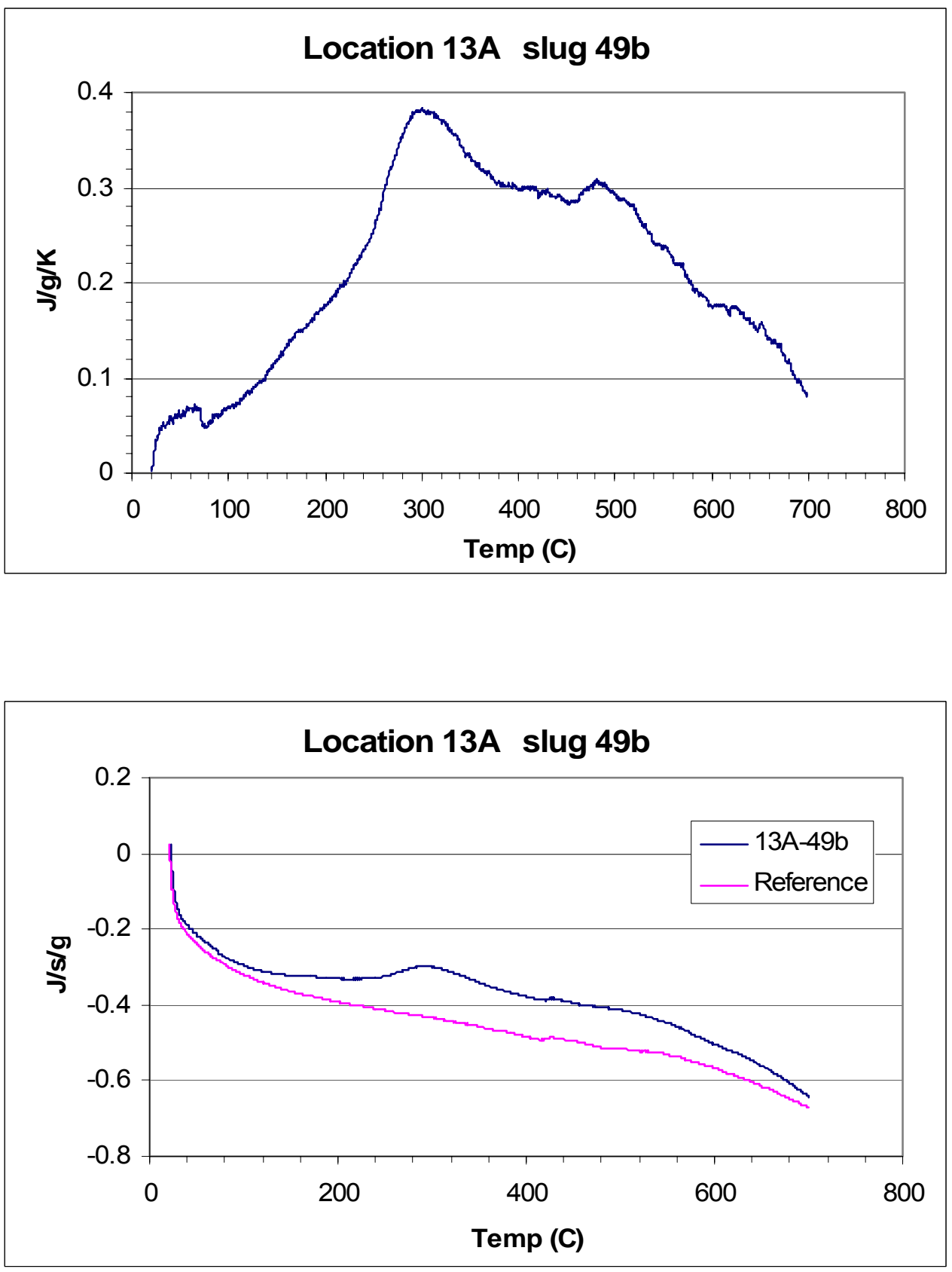